\title{
Teaching about the Shoah: Critical issues for educators
}

\author{
Clementina Acedo
}

Published online: 9 July 2010

(C) UNESCO IBE 2010

This second volume of Prospects' double issue on Holocaust education continues to reflect its authors' practical and intellectual engagement with the implications of Holocaust education for human rights, multicultural, peace, and civic education.

The volume opens with a powerful Viewpoint authored by Yehuda Bauer, a leading historian and scholar of the Holocaust. He takes a stand on a debated issue, often in implicit dialogue with other scholars, by strongly arguing against the equation between Stalinism and Nazism. Bauer appeals to historical facts to define the Holocaust as "the most extreme case embedded in a Nazi genocidal policy" and one that should never be repeated.

The title of his Viewpoint, "Understanding Holocaust: Some problems for educators", bears indirectly on the complexity of the Holocaust education field and hints at the inherent difficulties that affect the relationship between its policies and practices worldwide. Voiced in this volume are critical issues relevant to educators' approaches to Holocaust education, including the relationship between pedagogical intentions and classroom interaction, developing civic leaders through experiential learning, Holocaust remembrance and human rights education, positive values and gender in relation to Holocaust education, measuring knowledge of the Holocaust, and perceptions of justice emerging in cross-cultural discussions about the meaning of the Holocaust.

The authors approach these topics through international examples, from countries including Canada, Estonia, Germany, Scotland, Switzerland, and the US.

Wolfgang Meseth and Matthias Proske examine how instruction on "a morally fraught topic", the history of National Socialism in Germany, plays out in practice. Drawing on four case studies, they reveal the tensions between pedagogical intentions and classroom interaction. The authors find out that the organizational framework of schools and the specific conditions of classroom interaction shape the treatment of National Socialism. They argue that the ways in which students appropriate knowledge often conflict with the intended content of the lessons and with public expectations for the treatment of Germany's past. The article stresses the importance of the link between the quality of

C. Acedo $(\triangle)$

UNESCO IBE, P.O. Box 199, 1211 Geneva 20, Switzerland

e-mail: c.acedo@ibe.unesco.org; s.popa@unesco.org 
history teaching and the ability to take advantage of opportunities as they present themselves in specific classroom situations.

Carol Clyde looks at the impact that involvement in an experiential learning programme for Holocaust education had on its college and university participants' worldviews and civic leadership development. The travel programme to Poland was meant to empower its participants, and to involve them in civic leadership activities to reduce and ultimately prevent future human rights violations. Her findings show that, indeed, experiential learning programmes have the potential to influence college and university students in ways that may never be realized through traditional educational approaches that involve textbooks and lectures.

Paula Cowan and Henry Maitles analyze how the growth of Holocaust education in Scotland over the last decade has been influenced by the country's changing curriculum, the introduction of Holocaust Memorial Day, and the Lessons from Auschwitz Project. The authors conclude that these three initiatives should be made sustainable, especially through constant government support, in order to maintain the high impact of Holocaust and genocide education in Scotland.

Thomas Schlag and Oliver Wäckerlig argue that, even though the Swiss people might not have been actively involved in the activities of World War II and the cruelties of the Holocaust, Holocaust education and human rights education should become important cornerstones of Swiss educational policy. This would motivate teachers, students, and the whole society to learn more about the European history of which Switzerland is an integral part, and to make them better citizens, with a greater understanding and sensitivity to human rights, tolerance, and democracy.

Jack Jedwab analyzes the responses of some 1,500 Canadians to a public opinion survey on knowledge of the Holocaust, awareness of genocide, and attitudes towards discrimination and diversity. His findings show strong correlations between greater reported Holocaust knowledge and concern over genocide, as well as greater recognition of antiSemitism as a societal problem. However, greater reported Holocaust knowledge did not correlate consistently with greater openness towards diversity. Thus, the author argues, further research is needed on the relationship between these two elements, along with a deeper examination of what students learn about diversity and the limits of the effect of Holocaust education in this regard. Finally, the author makes a case for a global assessment of levels of Holocaust knowledge, as it connects to multicultural and citizenship education.

Doyle Stevick attempts to understand why Estonia's Holocaust education policy largely failed and why foreign efforts to prompt change were mostly ineffective. In his view, these outcomes relate closely to the backdrop of international efforts to prosecute Nazi war criminals and the changing geopolitics of the European Union after Estonia's accession. This new context, Stevick argues, allowed Estonia and other Central and East European countries "to change their stance on education about the Holocaust from subtly resisting foreign pressure to actively promoting an alternative vision of World War II for Europe's schoolchildren".

The variety of topics, along with the combination of empirical research and reflection used in these articles, partly account for the apparently heterogeneous nature of this double special issue. However, the unity of these two volumes, which underpins the articles' relationships with one another and with the topics they analyze, is evident throughout. The elaborated intellectual effort of the authors and guest editors of this special issue contributes; above all, to a profound elucidation of the way in which ideas like citizenship, diversity, human rights, morality, peace, and remembrance develop in relation to Holocaust education. 
The diversity of themes and research methods is truly illustrative of the complexity of Holocaust education - a burgeoning field, largely untrodden, which lies at the intersection of education, history, philosophy, political science, and sociology. I would like to re-emphasize the importance of continuous dialogue on the policies and practices of Holocaust education, as a means to learn how to become better citizens and human beings, in pursuit of peace, diversity, and respect for others.

Acknowledgment My special thanks to Simona Popa for her significant contribution to the writing of this editorial. 